\title{
Surveying Curriculum from the Point of View of Multidisciplinarity
}

\author{
Václav Slaboch \\ CLGE, Vice President for Professional Education \\ vaclavs.vaclavs seznam.cz
}

Keywords: Multidisciplinarity, Modern curriculum for Surveying Education, role of CLGE, multilateral Agreement of Mutual recognition of qualification. Necessity of a CPD system for Surveying Profession.

\section{Summary}

The multidisciplinarity and globalization makes fade the differences among professions and surveying is no exception. CLGE - CLGE has a name in two of the many European languages English and French, namely "The Council of European Geodetic Surveyors" and "Comité de Liaison des Géomètres Européens". A "Multilateral Agreement" on mutual recognition of qualification in surveying was signed in 2005 in Brussels by representatives of Germany, France, Belgium, Switzerland and Luxembourg. In 2006 also Slovakia joint this Agreement. The signature by the Czech Republic is recently under discussion.

\section{Multidisciplinarity and globalization and their influence on surveying}

The multidisciplinarity in our profession is nothing new. A good example might be the Famous Italian Surveyor an architect Domenico Martinelli (1650-1718) to whom an European Research Project financed from ERDF (European Regional Development Fund) has been dedicated. Martinelli was not a mere surveyor, but also a diplomat, judge, valuer, professor and architect. By the way his multidisciplinarity is typical even for present Italian surveyors. Martinelli's relations to Czechia are represented namely through his diplomatic services for count Kounic, during his diplomatic mission in as emperor's ambassador in the Dutch Hague in 1698. One of the most famous architectonical project of Martineli is the château Slavkov by Brno (Austerlitz). Partners of this Project are, Universität Wien, Faculty of Philosophy of the Masaryk University in Brno, Senate of the Czech Republic, Liechtenstein Museum Vienna, U.S. Embassy in Prague and the Town of Rousínov. It might be worth while considering to launch a similar interregional project dedicated to real estate cadastre covering the countries of the former Austro-Hungarian Cadastre (Czechia, Slovakia, Hungary, Austria, Croatia, Slovenia, Italy). In fact this co-operation already exists, but it might be enlarged by France, Belgium and maybe even Denmark. Why this enlargement e.g. by France? Because the 
Czech Society of Surveyors and Cartographers is one of the founding members of the FGF (Federation de Géometrs Francophone) and also because the so called Napoleonian Cadastre is based on the same principles as the former Austro-Hungarian Cadastre. The new definition of the functions of the surveyor as adopted by the FIG General Assembly in Athens in May 2004 is a typical example of a multidisciplinary approach to our profession.

\section{Main Points of the New Definition of Surveying Profession as Adopted by FIG and CLGE:}

A surveyor is a professional person with the academic qualifications and technical expertise to conduct one, or more, of the following activities:

- to determine, measure and represent land, three-dimensional objects, point-fields and trajectories;

- to assemble and interpret land and geographically related information;

- to use that information for the planning and efficient administration of the land, the sea and any structures thereon; and,

- to conduct research into the above practices and to develop them.

\section{CLGE and their mission}

CLGE has a name in two of the many European languages English and French, namely "The Council of European Geodetic Surveyors" and "Comité de Liaison des Géomètres Européens". This has arisen because the business of the council is conducted in English, and the language of the European Courts of Justice is French. The accepted abbreviation in all languages is "CLGE". CLGE was established at the Féderation Internationale des Géomètres (F.I.G.). Congress in Wiesbaden in 1972 by the then 9 member States of the EEC to consider the implementation of the Treaty of Rome in relation to the profession of geodetic surveying. CLGE represents in Europe the geodetic surveyors in 23 States, which includes 22 member states and Norway, Switzerland too.

\section{The purpose and objectives of the CLGE}

The purpose of CLGE is to represent and to promote the interest of the geodetic surveying profession in the private and public sector in Europe, especially to the Institutions of the European Union. The aim is to enhance the development of the profession both administratively, educationally and scientifically, to facilitate training, continuous professional development and mutual recognition and to promote the activities of geodetic surveyors as a highly qualified profession.

\section{Liaison with the European Commissions}

CLGE has nominated a liaison Officer to open and maintain contact with the European Commission. Links have already been established with DG 12, 15 and 22.

The Executive Board consisting of

- President 
- The President is chairman of the General Assembly and the Executive Board

- Vice President for professional Education

- Vice President for professional Practice

- Vice President for European Relations

As permanent members:

- Secretary-General

- Treasurer

\section{Multilateral Agreement on mutual recognition of professional qualifications of public appointed surveyors}

On 24th October 2004 representatives of Surveying Profession from Switzerland, Germany, France, Belgium, Austria, Luxembourg and Denmark signed the following Multilateral Agreement. In 2006 this Agreement was also signed by Slovakia.

Preamble

The basis of all commercial and financial activity is confidence in the security of the legal system relating to land and property. National constitutions protect ownership of land and property and subject commercial and financial activity to strict procedures of a formal nature. In central European countries, comprehensive and legally binding documentation relating to ownership of land and property is assured traditionally by the technical-legal system of "the land register - real estate cadaster". The keeping of ownership and mortgage registers as well as real estate cadasters is a matter for the State. Codified procedures for registration and changes to entries therein must be compatible in all three areas in order to assure the necessary security. The presumed correctness of registers is reflected in the Real Estate Cadastre in the presumption of correctness of the cadastre entries in terms of location of the property boundaries and the designation of properties. Furthermore, real estate cadastre contains much more information which is essential for the functioning of the State, for the commercial and scientific utilisation of the surface of the earth, for avoidance of hazards and for nature protection and for safety in planning and civil engineering.

As changes in the registries of State and commercial interests arise in terms of place and time in a random fashion by their very nature, central European States have made use of the instrument of delegation of State functions for the past three hundred years. Specially trained reliable persons such as notary-publics or publicly commissioned geometers have been selected for this function. The multiplicity of public and private laws and legal effects relating to land and property calls for impartiality, reliability and comprehensive technical and legal knowledge on the part of members of the profession.

Protection of ownership as a basis of an economy starts out very simply with confidence in the publicly commissioned geometer as an individual who, without regard to person, sets out the boundaries of the property and the rights accruing from the property and thus lays the foundation for the implementation of constitutional dictates for protection of ownership of land and property. The complexity of land rights in modern economies calls for thorough 
command of technical and legal knowledge relating to land and property on the part of the geometer commissioned with these duties in order to be able to carry out this function. In central Europe, public registers covering ownership are quite diverse. The complexity of regulations is increasing in modern economies because land as a resource is coming to play an ever more important role and is being circumscribed in diverse legal manners. The legal framework within which the commissioned geometer operates differs from one country to the next and continues to develop.

\section{A profession for public functions}

Geometers commissioned to perform public functions are known in a number of countries:

$\begin{array}{llll}\text { in } & \text { France } & \text { as } & \text { Géomètre-Expert, } \\ \text { in Germany } & \text { as Öffentlich bestellter Vermessungsingenieur, } \\ \text { in Belgium } & \text { as Géomètre-Expert / Landmeter-Expert, } \\ \text { in Denmark } & \text { as } \text { Praktiserende Landinspektører, } \\ \text { in Austria } & \text { as Ingenieurkonsulent für Vermessungswesen, } \\ \text { in Switzerland } & \text { as } & \text { patentierter Ingenieurgeometer,/ ingénieur géomètre breveté, } \\ \text { in Luxembourg } & \text { as } \text { Géomètre-Officiell. }\end{array}$

With this delegation of functions, States pursue the aim of opening up public functions to competition and reducing costs as well as improving the effectiveness of public registers in the economy. In this context, the appointment of a highly qualified member of the liberal professions is an advantage for citizens in their function as consumers as they can select their service provider from the pool of competing, commissioned individuals all of whom are on an equal footing. It has been proven historically that the organizational form of the liberal professions, under State supervision in terms of personnel and specialist knowledge, or in selfadministration in conjunction with efficiency-based competition is the form which discharges public functions for State and for commercial interests most efficiently in the long term. In the above-mentioned countries, there are roughly 4,500 offices with one or several members of the profession.

\section{Professional rules govern public appointment}

In the respective countries, the professions are based on legislation governing the particular profession which regulates duties assumed, entry requirements to and ethics of the profession. In addition, there are procedural laws which set out the professional scope of work. These relate to areas of real estate, planning and civil engineering. The core of the profession is to be found in being commissioned to perform surveying work in the respective property securing system. Moreover, the profession rests on the following pillars:

- cadastral survey and safeguarding property boundaries, privately commissioned

- documentation of property surveying (i.e. keeping registers, measures, computations and maps, publicly commissioned)

- national geodetic survey

- geomatics / geoinformation / topography / hydrography

- certification of facts relating to land and property 
- work as technical expert reflecting the whole range of the professional formation

- application of laws relating to land and property

- real estate valuation

These are public functions, referred to as "sovereign" in some countries; as a rule, a member of the profession is permitted to take on assignments in the context of private law, if such do not give rise to a conflict of interest with the legal independence of the said member. Commissioning a member of the profession to carry out public work (delegation) is by government bodies or professional boards. In France, Belgium and Luxembourg, the géomètre-expert is the link from the property tax cadastre to ownership. In the German Federal states, members of the profession also issue administrative acts in their own right, in Austria, they issue official documents, in Switzerland, they carry out surveying and administer the comprehensive official Swiss surveying activities. In all countries the consultation of the consumer concerning the limitations of the real estate property due to the legal contents and geometry of the boundaries is the first duty of the profession. In no country are the numbers of members of the profession restricted by Government or self-administration; on the contrary, once members of the profession have provided proof of the necessary qualification, they have a right to admission. In that way, newcomers can always enter the profession. In all signatory states, there is a general trend towards an increase in delegating State functions to commissioned free-lance geometers.

\section{Entry to the profession and its European dimensions}

Regulations relating to entry to the profession vary from one country to another, however they are very similar and are in terms of their nature essentially of the same kind.

Demonstration of attainment of the necessary qualification involves, apart from an academic course of study for surveyors $(\mathrm{Bac}+5 \mathrm{U})$ the following general fields of study

- Administrative law,

- Land law,

- Building and planning law.

University education provides a widely available and comparatively equivalent, defined knowledge base. Thus, it has not been problematic to-date to perform straight-forward surveying techniques in a cross-border context (for a non-commissioned geometer or surveying technician). This happens very often. The education set out below thus relates to practice and legal issues arising in the particular national legal system. There is, however, no possibility of exercising the public functions of a commissioned geometer on a cross-border basis. The regulatory situation on the one hand and the de facto impossibility of mastering two legal systems in sufficient professional depth have precluded this to-date, not to speak of other formal obstacles. Otherwise the right of public certification of facts is used in cross border service already now.

Nonetheless, the situation in the sector is in a constant state of flux, the legal systems are being investigated mutually and knowledge is disseminated transnationally over borders, not least by international associations such as GEOMETER EUROPAS. In addition, the EU is 
moving slowly in the direction of a harmonization of laws which also presupposes mutual understanding as a prerequisite.

As this is of major importance economically, this initiative of the signatory states also has the objective of making knowledge of practice of the profession more transparent in a legal and technical context and of drawing up common European positions in this sector. The larger this block of common European knowledge is, the sooner universities and training institutions can take account of it. This makes it easier for those entering the profession to avail of the possibility of working in the European country of choice, with all well-known associated economic advantages. This likewise serves to achieve a stepwise harmonization of systems and their use to the benefit of the European population.

\section{Illustration of the hitherto existing prerequisites for admission}

Differences between countries having publicly commissioned geometers are, when seen in isolation, multifold and, in addition, vary between French and German speaking areas but, in summary, they produce geometers who can function well within the respective legal system.

For the individual countries, the following regulations apply:

\begin{tabular}{|c|c|c|c|c|c|}
\hline Country & Master & $\begin{array}{l}\text { Professional } \\
\text { practice (after } \\
\text { BAC }+5 \text { ) }\end{array}$ & Exam & Other & $\begin{array}{l}\text { Right } \\
\text { to being } \\
\text { admit- } \\
\text { ted }\end{array}$ \\
\hline France: & $\mathrm{BAC} 1+5 \mathrm{U} 2$ & $2 \mathrm{P}$ & $\begin{array}{l}\text { Appraisal of } \\
\text { work certifi- } \\
\text { cates: D.P.L.G. } \\
\text { (in case of basic } \\
\text { education at a } \\
\text { State school) }\end{array}$ & & yes \\
\hline Germany: & $\mathrm{BAC}+5 \mathrm{U}$ & $\begin{array}{l}1 \mathrm{P} \text { after State } \\
\text { examination }\end{array}$ & $\begin{array}{l}\text { State examina- } \\
\text { tion }\end{array}$ & $2 \mathrm{R}$ & yes \\
\hline Belgium: & $\begin{array}{l}\mathrm{BAC}+4 \mathrm{U} \\
(\text { in future: } \\
\mathrm{BAC}+5 \mathrm{U})\end{array}$ & $0 \mathrm{P}(2 \mathrm{P})$ & without & & $\begin{array}{l}\text { "Con- } \\
\text { vention" }\end{array}$ \\
\hline Denmark: & $\mathrm{BAC}+5 \mathrm{U}$ & $3 \mathrm{P}$ & $\begin{array}{l}\text { Selection based } \\
\text { on work certifi- } \\
\text { cates }\end{array}$ & & yes \\
\hline Austria: & $\mathrm{BAC}+5 \mathrm{U}$ & $3 \mathrm{P}$ & $\begin{array}{l}\text { External exami- } \\
\text { nation }\end{array}$ & & yes \\
\hline Switzerland: & $\mathrm{BAC}+5 \mathrm{U}$ & min. 18 months & $\begin{array}{l}\text { External exami- } \\
\text { nation }\end{array}$ & & yes \\
\hline Luxembourg: & $\mathrm{BAC}+5 \mathrm{U}$ & $\begin{array}{l}2 \quad \mathrm{P} \quad(\min \quad 6 \\
\text { months } \\
\text { cadaster admin- } \\
\text { istration) }\end{array}$ & Examination & & \\
\hline
\end{tabular}

Legend: 
BAC $+5 \mathrm{U}:$ Baccalaureat +5 -year study at a university / technical university

P: On-the-job training in law and work practice in the respective country after university study

R: compulsory monitored experience prior to the Great state examination (two years)

In various countries, legal professional regulations also allow holders of a degree from a technical university to enter, if they can provide evidence of relevant technical and legal knowledge (and a longer practical training). This is regulated by national law.

\section{Current admission and examination institutions}

The current examination and admission institutions are state institutions or legally established boards

\begin{tabular}{|l|l|l|}
\hline Country & Examination authority & Admission authority \\
\hline France: & Ministry of Education (for DPLG) & Ordre des Géomètres Experts \\
\hline Germany: & $\begin{array}{l}\text { principally the Oberprüfungsamt } \\
\text { (Higher Examination Office) } \\
\text { Frankfurt }\end{array}$ & Ministries of the Federal laender \\
\hline Belgium: & $\begin{array}{l}\text { Communautés (VL+ W) Asser- } \\
\text { mente Tribunal de 1ere Instance }\end{array}$ & $\begin{array}{l}\text { Conseils Federaux des Geometres- } \\
\text { Experts }\end{array}$ \\
\hline Denmark: & $\begin{array}{l}\text { Supreme Land Surveying Author- } \\
\text { ity }\end{array}$ & $\begin{array}{l}\text { Supreme Land Surveying Author- } \\
\text { ity }\end{array}$ \\
\hline Austria: & $\begin{array}{l}\text { Federal Ministry of Economics and } \\
\text { Labour }\end{array}$ & $\begin{array}{l}\text { Federal Ministry of Economics and } \\
\text { Labour }\end{array}$ \\
\hline Switzerland: & $\begin{array}{l}\text { Swiss examination commission } \\
\text { EPIG }\end{array}$ & Executive Federal Council \\
\hline Luxembourg: & $\begin{array}{l}\text { Examination commission ap- } \\
\text { pointed by the Minister }\end{array}$ & Ministry of Finance \\
\hline
\end{tabular}

\section{Mutual recognition of qualifications for admission to the profession}

The signatory states mutually recognize the qualifications for admission to the profession of a European Geometer and agree on a procedural modus for ensuring unimpeded migration of members of the profession - irrespective of the directive 89/48 - on the following basis:

Training as a graduate engineer $(\mathrm{Bac}+5)$ in surveying or Master (if compatible) is recognized automatically as an educational foundation. In additional, each candidate must acquire necessary country-specific extra qualifications in the area of

- administrative law,

- land law,

- building and planning law.

Qualifications for admission to the profession shall then be based on a common, general platform

Diploma-engineer / European Master $(\mathrm{BAC}+5 \mathrm{U})+2 \mathrm{R} / \mathrm{P}+\mathrm{E}$ 


\section{Treatment of migrants after obtaining qualification in a signatory state}

The signatory associations support such migrants to provide them with the opportunity of evidencing the required knowledge in

- administrative law,

- land law,

- building and planning law.

of the respective country and of fulfilling the European platform requirements in terms of legal admission regulations. The admitting member states might value the elements of the formation and experience of the migrant and give him the choice between training seminar and an examination to prove his acceptability.

\section{References webliography and bibliography}

1. Internet homesite of the CLGE - www.clge.eu

2. Internet homesite of the FIG - the International Federation of Surveyors - www.fig.net

3. FIG Definition of Functions of the Surveyor ${ }^{1}$ as adopted by the FIG General Assembly on 24 May 2004

4. EU Interreg Project Domenico Martinelli² (1650-1718) Italian surveyor and architect

5. ZEMĚMĚŘIČ a Czech Monthly for surveying, Cadastre and Cartography ${ }^{3}$. The new definition of Surveying profession - illustrated

6. Internet home site of the VUGTK - www.vugtk.cz - the Research Institute of Geodesy, Topography and Cartography at Zdiby, with the Land Surveying Library where the originals and the Czech translations of majority of the cited documents are now available.

7. Otmar SCHUSTER: Multilateral Agreement. Proceedings from the International CLGE Conference at the RM in Brussels, 1-2 December 2005. VÚGTK, Volume 52, Publication No. 39, ISBN 80-85881-14-4

8. Stig ENEMARK, tom KENNIE: CPD - Continuig Professional Development and its future promotion within FIG- in Surveying. FIG Publication No. 15.

9. Vaclav SLABOCH, Frantisek KRPATA, Josef WEIGEL: Surveying education in the Czech Republic

10. Otmar SCHUSTER: Surveying Market in Europe. CLGE publication, 2004

11. Vaclav SLABOCH, Jean-Yves PIRLOT(edts): European Professional Qualifications In Geodetic Surveying, Proceedings of the CLGE International Conference 2005, Brus-

\footnotetext{
${ }^{1}$ http://www.fig.net/general/definition.htm

${ }^{2}$ http://www.domenico-martinelli.com/index_en.html

${ }^{3}$ http://www.geos.cz/resort/definice.htm
} 
sels/Belgium, 1-2 December 2005, VÚGTK, Volume 52, Publication No. 39, ISBN 80-85881-14-4

12. Vaclav SLABOCH: Impacts and Challenges of the EU Membership on Surveying Profession in the Czech Republic. In: 1st International Trade Fair of Geodesy, Cartography, Navigation and Geoinformatics, GEOS 2006, Conference Proceedings, Milan Talich (Ed), VÚGTK, Volume 52, Publication No. 40, ISBN 80-85881-25-X. 
